SIR - The leading article (Nature 14 February, p. 515) on what you call the prospectus for the Natural Environment Research Council (NERC) contains a good breakdown of our present problems. Your conclusions do not follow. Having made the case for greater cohesion in the field of environmental research and touched on the history of why there is none, the answer is not as you suggest the dismemberment of NERC.

Early drafts of the corporate plan had the idea of submerging the research institutes in the new science divisions. Greater cohesion and flexibility may well come from abolishing the institutes, at the cost of more centralization. The plan published on 14 February was ambiguous. The absence from NERC of mainstream meteorological work is serious, but the corporate plan seeks to include work on climate. The main aim of the plan in its present form is to preserve university grants at a meaningful level. You rightly point out that in five years the universities will hardly notice the benefit. In contrast, in the same period, the funding to institute research could fall by up to 50 per cent and much long-term research will have been written off.

In the British Geological Survey (BGS) many staff feel a new home is necessary. They are committed to the need for continued survey but cannot carry out that task without an adequate level of dedicated funding. BGS finds no stability of finance within NERC and has been the target for an unfair share of cuts already. The proposal that BGS could find an umbrella similar to the British Antarctic Survey is as illogical as it is unlikely. No obvious slot exists for BGS and the present government would never sanction either the making of a new quango or the subsuming of 1,500 extra civil servants into an existing department.

The position of BGS outside central government gives a freedom with which only privatization might compare. The disadvantages of the latter course to the majority of staff and to the scientific needs of the community are obvious.

In the case of the Institute of Terrestrial Ecology (ITE), it is now untrue to say that any greater research links exist with the Nature Conservancy Council (NCC) than with any other government agency with interests in the biological environment. Scientists in ITE see a much wider role in the applied field of pollution studies and all aspects of land use, notably forestry and agriculture. The Ministry of Agriculture, Fisheries and Food and the Agricultural and Food Research Council have been slow to encompass sound ecological principles in answering environmental concerns. The House of Lords Select Committee report on agriculture and the environment (1984) came out in favour of much better liaison in research. Any return of ITE to a functional link with NCC would restrict the research scope and increase the accusation that the institute is simply an advocate of nature conservation. This denies the relevance of ecological work to a whole range of human activities. In any case research should be conducted away from the shackles of departmental policies.

Returning to the leading article of 14 February, your analysis of events leading to the NERC corporate plan was right, but the basic problem is the government's insistence on cuts. As its prescription may not change, it is best to look at what can be salvaged.

I have stated above why for dogmatic reasons the carving up of NERC will not suit the government either. It may be possible to persuade it to accept the proper integration of environmental science in the United Kingdom. In doing so it may get economies and take out some duplicated effort. To allow the fragmentation of NERC would make even more tenuous the links between disciplines and weaken research effort in key areas. This must not happen. Though we are against the planned 30 per cent cut in NERC manpower, we support the need for a properly directed and capitalized research council in the United Kingdom. It is our belief that reduction of institute strength and further fragmentation of research is not the way forward.

RICHARD SCOTT (Chairman, Union side)

Institute of Terrestrial Ecology, Merlewood Research Station,

Grange-over-Sands,

Cumbria LA11 6JU, UK

SIR - Given the now unavoidable association between the Natural Environment Research Council (NERC) corporate plan and the notion that a 3,000-strong workforce is to be reduced to 2,000 , the choice of St V.alentine's Day to announce the contents of such a melancholy document seemed at first sight inapposite until it is remembered that this feast day for romantics also commemorates a notorious massacre.

It may be about to commemorate another one - the sacrifice of the institutes on the altar of the universities. One of the principles underlying the plan and one that appears to have become axiomatic and therefore apparently beyond discussion (see Nature 31 January, p.340), is the transferring of institute resources to make up for the shortfall in government financial support for the universities. The plan is obviously modelled on the Mason report into the research councils which made canonical the notion that university research was more flexible and therefore better than the research of the institutes.
Nowhere is the term "flexibility" defined or explained. It must be assumed in the absence of an explanation that flexibility in some way refers to an organization's response to the changing times we live in. In other words, it seems flexibility may mean how organizations respond to what has become almost the universal arbitrator the market forces.

Terrestrial and fresh water ecology seem to have been earmarked for a large contribution towards the "Save the Universities Fund", yet the Institute of Terrestrial Ecology (ITE), for example, was born out of a not dissimilar transfer of funds a decade ago when a substantial percentage of its money was handed over from the Department of Education and Science with the Nature Conservancy Council (NCC) to the Department of the Environment, where NCC was to be a major customer of ITE and any other organization that chose to tender for NCC contracts. ITE has had to compete, and still does compete, with the universities among others for that money. If the universities are not able to obtain enough of that money through competition, are we to understand they will instead be given a proportion of, in this instance, ITE's funds instead? If this is so, how does this principle of flexibility operate other than to appear as a word whose context leaves it without meaning but with a use, namely that of a magic wand with which to shrink institutes.

In place of a more satisfactory explanation of the apparently fundamental concept of flexibility, perhaps there should be much wider consultation, not only on the "details" (ibid) but on the principles of the corporate plan.

Otherwise the more cynical employees of NERC institutes may just come to the conclusion that, since the institutes have no direct voice on council and the universities have many, what is being witnessed is not a "rational reconstruction" but something quite different.

Barrie Pearson

13 Knoll Cottage Residential Park,

Winfrith, Dorchester,

Dorset DT2 8LD, UK

\section{Embryo research}

SIR - The question "who can object to the proposition that there can be no such thing as a living being without implantation?" posed in your Opinion column (Nature 21 February, p.612) fails to address the objections to embryo research. In my mind the issue is not the point at which an embryo becomes a viable organism, but rather the point at which a unique potential member of our species is created. There can be no objections to the proposition that this takes place at fertilization.

14 Eldon Avenue,

ROGER WATSON

Shirley,

Croydon CRO 8SD,

Surrey, UK 